\title{
PERISTOMAL INFECTION AFTER PERCUTANEOUS ENDOSCOPIC GASTROSTOMY: a 7-year surveillance of 297 patients
}

\author{
Helena DUARTE ${ }^{1,2}$, Carla SANTOS ${ }^{2}$, Manuel Luís CAPELAS ${ }^{3}$ and Jorge FONSECA ${ }^{2}$
}

\begin{abstract}
Context - Healthcare-associated infection represents the most frequent adverse event during care delivery. Medical advances like percutaneous endoscopic gastrostomy have brought improvement on quality of life to patients but an increased risk of healthcare-associated infection. Predictive risk factors for peristomal wound infection are largely unknown but evidence suggests that antibiotic prophylaxis and preventive strategies related to infection control may reduce infection rates. Objectives - The primary aim was to evaluate the global prevalence rate of peristomal infection. Secondary objectives were to characterise the positive culture results, to evaluate the prophylactic antibiotic protocol and to identify potential risk factors for peristomal infection. Methods - Retrospective study of 297 patients with percutaneous endoscopic gastrostomy performed at a general hospital between January 2004 and September 2010. Patients received prophylactic cefazolin before the endoscopic gastrostomy procedure. Medical records were reviewed for demographic data, underling disease conditions to percutaneous endoscopic gastrostomy and patient potential intrinsic risk factors. Statistical analysis was made with the statistical program SPSS 17.0. Results - A total of 297 percutaneous endoscopic gastrostomy tubes were inserted. Wound infection occurred in 36 patients (12.1\%). Staphylococcus aureus methicillin resistant was the most frequently isolated microorganism (33.3\%) followed by Pseudomonas aeruginosa (30.6\%). The incidence rate had been rising each year and differ from $4.65 \%$ in $2004 / 2007$ to $17.9 \%$ in 2008/2010. This finding was consistent with the increasing of prevalence global infection rates of the hospital. Most of the infections (55.6\%) were detected in the first 10 days post procedure. There was no significant difference in age, body mass index values, mean survival time and duration of percutaneous endoscopic gastrostomy feeding between patients with and without periostomal infection. Institutional factors, namely global prevalence infection rates and the endemic character of Staphylococcus aureus methicillin resistant, play an important role in peristomal infection rates. Traditional antibiotic prophylaxis with cefazolin is not adequate due to the prevalence of resistant organisms. Conclusions - Peristomal infection is a frequent problem with clinical impact in percutaneous endoscopic gastrostomy patients and should be considered a healthcare associated infection. The antimicrobial prophylaxis regimens using cephalosporins are not adequate and need to be reviewed due to the high prevalence of Staphylococcus aureus methicillin resistant and other resistant organisms in hospitals and nursing homes. HEADINGS - Gastrostomy. Endoscopy, gastrointestinal. Wound infection. Staphylococcus aureus. Antibiotic prophylaxis.
\end{abstract}

\section{INTRODUCTION}

Healthcare-associated infection (HAI) is an infection which occurs during the patient's process of care in a hospital or other health care facility that is not present or incubating at time of admission ${ }^{(19)}$. HAI can appear after discharge and results in additional costs for health systems, increased resistance of microorganisms to antimicrobials and long term disability ${ }^{(5,10)}$.

The surgical site infection (SSI) is one of major types of HAI and, although endoscopic gastrostomy is not considered a surgery, an adaptation of the Centers for Disease Control (CDC) definitions for superficial surgical-site infection was been used to detect PEGsite infections ${ }^{(15,17)}$.
Peristomal infection should be considered a healthcare-associated infection, if it is detected within 30 days post-discharge, on account of being an invasive technique with a medical device that is left in place. The post discharge surveillance is essential because diagnose confined to the inpatient underestimates the rate of infection ${ }^{(8)}$.

Complications of percutaneous endoscopic gastrostomy (PEG) have been described in debilitated patients $^{(6)}$ and 30-day mortality rates of 4,1\%-26\% have been reported ${ }^{(1)}$. Rodriguez Ortega et al. ${ }^{(17)}$, in a Spanish study, found a 30-day-mortality of $8,69 \%$.

Peristomal wound infection occurs in 5\% to $39 \%$ of patients and is the most frequent PEG complica$\operatorname{tion}^{(13,21)}$.

Declared conflict of interest of all authors: none.

${ }^{1}$ Pharmacy Department; ${ }^{2}$ GENE - Grupo de Estudo de Nutrição Entérica - Enteral Feeding Team Hospital Garcia de Orta; ${ }^{3}$ Institute of Health Sciences, Catholic University of Portugal, Almada, Portugal.

Correspondence: Dr. Carla Santos - Hospital Garcia de Orta - Av. Prof. Torrado da Silva Pragal - 2805227 - Almada, Portugal. E-mail: nutrição.enterica@hotmail.com 
The increasing incidence of resistant organisms in hospitals and long term care facilities justifies, nowadays, the clinical impact of these infections ${ }^{(4,14)}$. In a hospital endemic for methicillin-resistant Staphylococcus aureus, MRSA can be the most common organism associated with peristomal infection $^{(17)}$. In 2011 The Infectious Diseases Society of America published the first guidelines for the treatment of MRSA infections in hospitals and ambulatory settings, which was an important step in the elaboration of new prophylactic and therapeutic protocols in health institutions ${ }^{(11)}$.

A cephalosporin-based prophylaxis is usually suggested to decrease peristomal infection after PEG insertion ${ }^{(2,18)}$ but these antibiotics are unlikely to be useful in the prevention of PEG-site infections caused by MRSA and resistant strains of Pseudomonas aeruginosa ${ }^{(9)}$. A recent paper in the British Medical Journal (BMJ) suggested the use of co-trimoxazol in the PEG prophylaxis ${ }^{(3)}$. This, however, is not a good option considering the rate of MRSA in our hospital (47\%).

This complication is a public health issue and the use of targeted surveillance, with data collected locally, may have benefits which can result in improvements in the quality of medical care ${ }^{(10)}$.

\section{OBJECTIVES}

The primary aim was to evaluate the global prevalence rate of peristomal infection between January 2004 and September 2010, and to characterise the microbiological characteristics of positive culture results. The secondary objectives were the evaluation of the prophylactic antibiotic protocol and study of potential risk factors (age, body mass index (BMI) values and length of time patients use PEG tubes) for peristomal infection.

\section{METHODS}

Medical records of adult patients who underwent endoscopic gastrostomy at a general hospital between January 2004 and September 2010 were reviewed. After given informed consent, patients had the gastrostomy placed by pull-method (Kimberly-Clark ${ }^{\circledR}$ or Bard ${ }^{\circledR}$ ). An intravenous

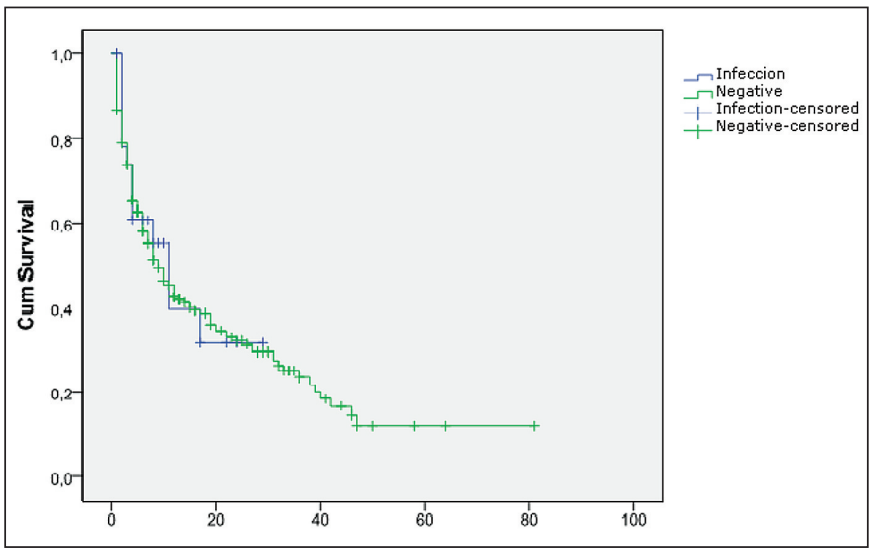

FIGURE 1. Kaplan-Meier survival curve prophylactic cefazolin $1 \mathrm{~g}$ was given 1 hour prior to the procedure. If patients were under antibiotic therapy for other diseases, the cefazolin was not given.

The peristomal infection was defined as a purulent discharge with positive wound culture according to CDC definitions for superficial surgical site infections. All the cultures isolates from peristomal wounds were analysed for the antibiogram using the disc diffusion method.

The PEG wound was cared for once every day by sterile saline with coverage of dry gauze placed between the external fixing device and the skin.

A post-discharge surveillance was performed until the patients died or regained oral intake, with multidisciplinary follow-up visits at 1, 3, 6, 12 months post PEG.

The statistical analysis of data was made with the statistical software SPSS 17.0 for Windows. The significance level was set at $5 \%$. Patients were classified in two groups according to the presence of peristomal infection. The comparison of the means for age, BMI and duration of PEG use between these groups was performed using the T-test for independent samples or Man-Whitney U test.

\section{RESULTS}

Our study included 297 patients, $210(70.7 \%)$ male and $87(29.3 \%)$ female. Mean age was $62.06 \pm 16.04$ years, mean BMI was $20,24 \pm 4,16 \mathrm{~kg} / \mathrm{m}^{2}$ and $37.3 \%$ of patients were malnourished $\left(\mathrm{BMI}<18.5 \mathrm{~kg} / \mathrm{m}^{2}\right)$.

Dysphagia due to neurological disease was the most common indication with $160(53.6 \%)$ patients. Oropharyngeal cancer in $109(36.7 \%)$ patients, other malignant diseases in $21(7.1 \%)$ patients and esophageal fistula in $7(2.4 \%)$ patients were the other underlying diseases for PEG placement.

There was no mortality related to the PEG insertion. The mean survival time was $21,36 \pm 2,13$ months (IC 95\%). According to survival analysis using the Kaplan-Meier method (Figure 1 ), the $30^{\text {th }}$ day mortality rate was $12.45 \%$. There was no significant difference between the median survival time of infected and non infected patients $(P>0.05)$.

Infections were mostly detected in the first 30 days post-procedure $(86.1 \%)$ and $55.6 \% 10$ days after PEG insertion.

The overall prevalence of peristomal infection was $12.1 \%$ (36/297 patients). A total of 41 microorganisms were isolated from these 36 patients (Figure 2). Five patients had

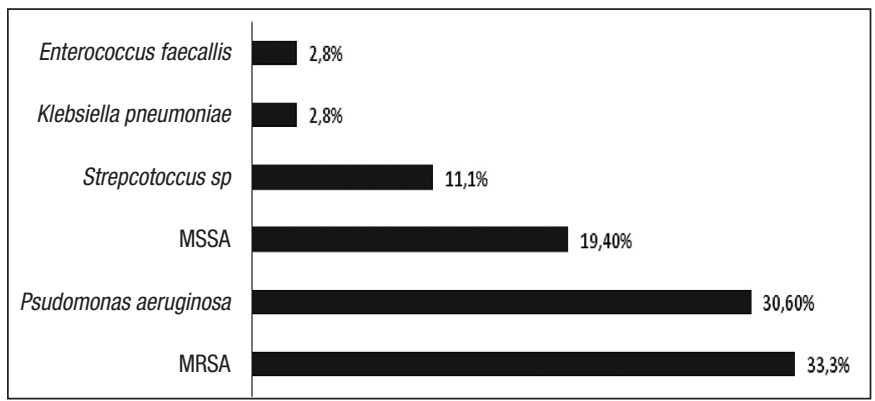

FIGURE 2. Prevalence of microorganisms isolated from wound culture between 2004 and 2010 


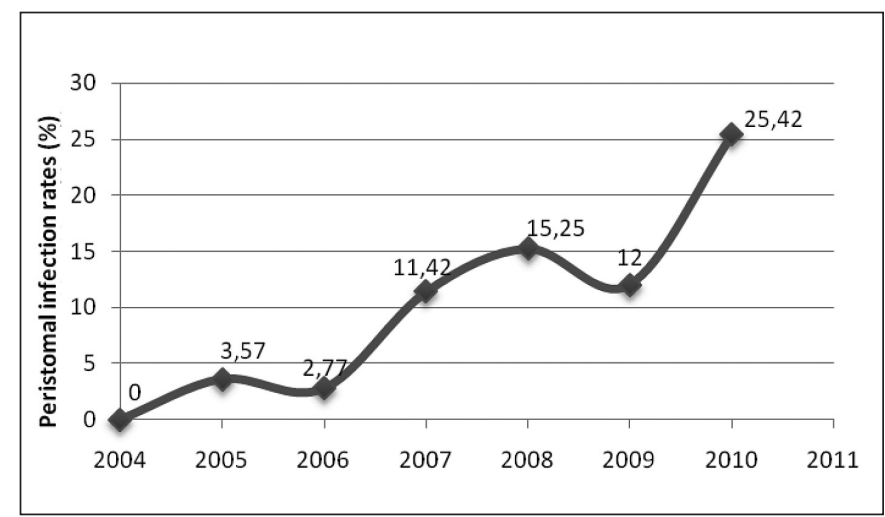

FIGURE 3. Prevalence of peristomal infection after PEG procedure

two organisms cultured. The PEG wound isolates included Staphylococcus aureus in 52.7\% (19/36) of patients, from which 12 strains were MRSA (33.3\% of global infections); Pseudomonas aeruginosa in 30.6\% (11/36) patients; Streptococcus $\beta$-haemolyticus in $11.1 \%$ (4/36), Klebsiella pneumoniae in $2.8 \%(1 / 36)$ and Enterococcus faecallis in $2.8 \%(1 / 36)$.

The incidence rate rose each year, increasing from $4.65 \%$ in $2004 / 2007$ to $17.9 \%$ in $2008 / 2010$ (Figure 3). The increasing of peristomal infection rate was consistent with the overall prevalence of nosocomial infection rates in our institution (Figure 4).

There were no differences between PEG patients with or without peristomal infection respecting to age, BMI values and duration of PEG feeding $(P>0.05)$.

\section{DISCUSSION}

In our study the 30 -day mortality rate was $12.5 \%$ lower then the reported in a large study in United States, in which all types of gastrostomy placement were included, the 30-day mortality was $23.9 \%$ and at 1 year was $63 \%{ }^{(1)}$. This may reflect a careful selection of patients and the experience of the team.

In previous series the rate of wound infection may differ significantly between $5 \%$ and $39 \% \%^{(13,14,21)}$. In our study, the overall peristomal infection rate was $12.1 \%$, an intermediate figure, but rising every year and over $25 \%$ in 2010 . Nevertheless, our overall peristomal infection rate was rising every year, reaching $25 \%$ in 2010 and a sustained high prevalence is expectable for next years.

In this retrospective analysis we were not able to find any independent intrinsic patient's risk factor for peristomal infection due to the high prevalence of co-morbidities in this cohort. A prospective randomized study is now being conducted in order to evaluate predictive risk factors.

Three important results of our study support the idea that peristomal infection must be considered a serious problem of healthcare associated infection:

1.the prevalence of peristomal infection has been rising, and this parallels the rising of general nosocomial infections in our hospital;

2. most infections $(55.6 \%)$ were detected in the first 10 days

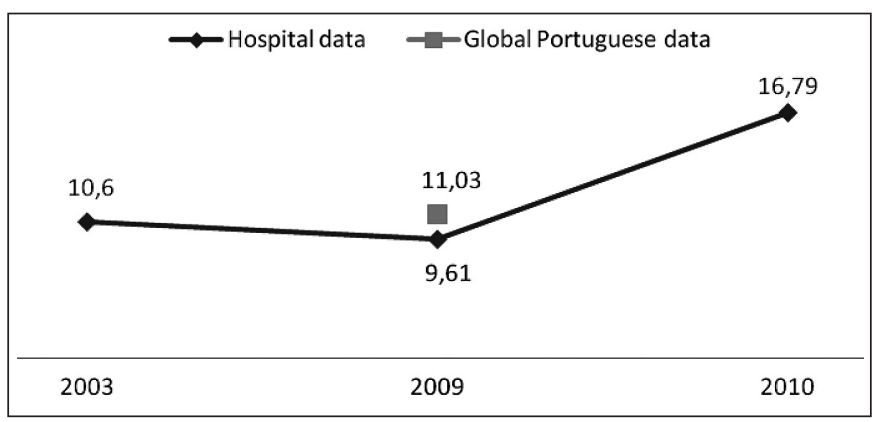

FIGURE 4. Prevalence of nosocomial infection rates between 2003 and $2010(\%)$

after gastrostomy and $86.1 \%$ within 30 days post-procedure $(86.1 \%)$. Globally, the large majority of peristomal infection occurred during the hospitalization period or shortly after discharge;

3.the microorganisms cultured from PEG wounds (MRSA, Pseudomonas aeruginosa, Klebsiella pneumoniae, Enterococcus faecallis, for example) reflect the nosocomial agents in the hospital.

The high prevalence of multiresistant bacteria was one of the most important findings of the present study. As anticipated by previous reports, multiresistant bacteria, namely MRSA, become the dominant pathogens ${ }^{(7,12,20)}$. Most PEG patients have multiple hospitalization episodes prior to the gastrostomy procedure, multiplying the chances of becoming colonized by multiresistant organisms. The use of broad-spectrum antibiotics before PEG insertion ${ }^{(13)}$ may also be an explanation for the high prevalence of Pseudomonas aeruginosa $(30.6 \%)$. Taking into consideration the rising of nosocomial infection and multiresistant bacteria, namely MRSA, in hospitals worldwide, we believe that in the future these agents will become more and more important in peristomal infection.

In order to reduce infectious complications, prophylactic antibiotics were recommended ${ }^{(18)}$. However, the widespread routine of large broad antibiotics might increase the risk of emerging resistant organisms. Rao et al. ${ }^{(16)}$ recommended the use of a glycopeptide prophylaxis based and a decontamination protocol before PEG insertion in order to reduce MRSA incidence rates in wound infections. Although the MRSAcolonization eradication therapy is not a good option due to the endemic character of the MRSA in the institution ${ }^{(11)}$, other MRSA infection-prevention strategies must be implemented, like pre-procedure antiseptic showering with clorhexidine and hand hygiene by all clinical staff ${ }^{(15)}$. In our opinion, PEG procedure antibiotic prophylaxis should be adapted to the prevalence of founded causative organisms. In institutions with high prevalence of MRSA, such as our hospital, the use of a glycopeptides prophylaxis should be considered.

\section{CONCLUSIONS}

In the present study, peristomal infection was a frequent and significant problem in PEG patients and should be 
considered as a healthcare associated infection. We did not found any independent risk factor for this infection.

In our recent experience, there was a high prevalence of multiresistant bacteria. Looking to the rising prevalence of MRSA and other resistant organisms in ours and other hospitals, and also in nursing homes, the classical antimicrobial prophylaxis regimens, such as those using cephalosporins, are not adequate anymore and need to be critically reviewed.

\section{ACKNOWLEDGEMENTS}

Duarte H, Santos C, Capelas ML, Fonseca J. Infecção peristomal na gastrostomia endoscópica percutânea: estudo de 297 doentes gastrostomizados ao longo de 7 anos. Arq Gastroenterol. 2012;49(4):255-8.

RESUMO - Contexto - As infeções associadas aos cuidados de saúde constituem o mais frequente efeito adverso observado durante a prestação de cuidados de saúde. Os avanços clínicos como a gastrostomia endoscópica percutânea melhoraram a qualidade de vida dos doentes mas trouxeram um risco acrescido de infeções associadas aos cuidados de saúde. Os fatores de risco para a infecção peristomal são pouco conhecidos, mas a profilaxia antibiótica e outras estratégias profiláticas parecem reduzir a infeção peristomal. Objetivos - O objetivo primário foi a avaliação global da taxa de infecção peristomal e a caracterização microbiológica dos agentes infetantes. Foram objetivos secundários a avaliação do protocolo de profilaxia antibiótica utilizado e a identificação de potenciais fatores de risco para a infeção peristomal. Método - Estudo retrospetivo em doentes submetidos a gastrostomia endoscópica entre janeiro de 2004 e setembro de 2010. Os doentes receberam profilaxia antibiótica com cefazolina antes do procedimento. Os processos clínicos foram revistos obtendo-se os dados demográficos, diagnóstico da doença subjacente e potenciais fatores de risco para infeção. A análise estatística foi feita com recurso ao programa SPSS 17.0. Resultados - Foram gastrostomizados 297 doentes adultos. A infeção peristomal afetou 36 doentes (12,1\%). O Staphylococcus aureus resistente à metacilina foi o micro-organismo mais frequentemente isolado (33,3\%) seguido pela Pseudomonas aeruginosa (30,6\%). A incidência de infeção peristomal aumentou progressivamente ao longo dos anos de 4,65\% em 2004/2007 até $17,9 \%$ em 2008/2010. Este achado foi consistente com o crescimento global da infeção hospitalar. A maioria das infeções peristomais (55,6\%) foi identificada nos primeiros 10 dias após a gastrostomia. Não encontramos diferenças significativas na prevalência da infeção peristomal relacionáveis com a idade, índice de massa corporal, sobrevida e duração da nutrição por gastrostomia endoscópica percutânea. Fatores institucionais, como a prevalência global da infeção hospitalar e o caráter endêmico do MRSA, são importantes na infeção peristomal e a profilaxia tradicional com cefazolina não é adequada num contexto de elevada prevalência de micro-organismos resistentes. Conclusões - A infeção peristomal é um problema frequente e clinicamente significativo que deve ser encarado como infeção associada aos cuidados de saúde. A profilaxia usando cefalosporinas pode não ser adequada e deve ser revista em hospitais e outras instituições com elevada prevalência de micro-organismos resistentes.

DESCRITORES - Gastrostomia. Endoscopia gastrointestinal. Infeção dos ferimentos. Staphylococcus aureus. Antibioticoprofilaxia.

\section{REFERENCES}

1. Abuksis G, Mor M, Segal N, Shemesh I, Plout S. Sulkes J, Fraser GM, Niv Y. Percutaneous endoscopic gastrostomy: high mortality rates in hospitalized patients. Am J Gastroenterol. 2000;95:128-32.

2. ASGE Standards of Practice Committee, Banerjee S, Shen B, Baron TH, Nelson DB, Anderson MA, Cash BD, Dominitz JA, Gan SI, Harrison ME, Ikenberry SO, Jagannath SB, Lichtenstein D, Fanelli RD, Lee K, van Guilder T, Stewart LE. Antibiotic prophylaxis for GI endoscopy. Gastrointest Endosc. 2008;67:791-8.

3. Blomberg J, Lagergren P, Martin L, Mattsson F, Lagergren J. Novel approach to antibiotic prophylaxis in percutaneous endoscopic gastrostomy (PEG): randomised controlled trial. BMJ. 2010;341:c3115. doi: 10.1136/bmj.c3115.

4. Chaudhary KA, Smith OJ, Cuddy PG, Clarkston WK. PEG-site infections: the emergence of methicillin resistant Staphylococcus aureus as a major pathogen. Am J Gastroenterol. 2002;97:1713-6.

5. European Center for Disease Prevention and Control. Antimicrobial resistance surveillance in Europe 2008. Annual report of the European Resistance Surveillance Network (EARS-net) [Internet]. Stockholm: ECDC; 2009. Aavalilable from: http://www.ecdc.europa.eu/healthtopics/antimicrobial_resistance.

6. Gauderer MW. Percutaneous endoscopic gastrostomy and the evolution of contemporary long-term enteral access. Clin Nutr. 2002;21:103-10.

7. Horiuchi A, Nakayama Y, Kajiyama M, Fujii H, Tanaka N. Nasopharyngeal decolonization of methicillin-resistant Staphylococcus aureus can reduce PEG peristomal wound infection. Am J Gastroenterol. 2006;101:274-7.

8. Hospital in Europe Link for Infection Control through Surveillance - HELICS Surveillance of surgical site infections. Protocol version 9.1 September 2004 [Internet]. Available from: http://helics.univ-lyon.fr/helichome.htm.

9. Hull M, Beane A, Bowen J, Settle C; Hospital Infection Society Steering Group. Methicillin-resistant Staphylococcus aureus infections of percutaneous endoscopic gastrostomy sites. Aliment Pharmacol Ther. 2001;15:1883-8.

10. Humphreys H, Newcombe RG, Enstone J, Smyth ET, McIlvenny G, Fitzpatrick F, Fry C, Spencer RC. Four country healthcare associated infections prevalence survey 2006: risk factor analysis. J Hosp Infect. 2008;69:249-57.

11. Infectious Diseases Society of America. Clinical practice guidelines by the infectious diseases society of America for the treatment of methicillin-resistan Staphylococcus aureus in adults and children. Clin Infect Dis. 2011;52:18-55.
12. Keely F, Williams J. Peristomal MRSA: a case study. Br J Nurs. 2009;18:s4, s6-8.

13. Lee JH, Kim JJ, Kim YH, Jang JK, Son HJ, Peck KR, Rhee PL, Paik SW, Rhee JC, Choi KW. Increased risk of peristomal wound infection after percutaneous endoscopic gastrostomy in patients with diabetes mellitus. Dig Liver Dis. 2002;34:857-61.

14. Mahadeva S, Khoo BL, Khoo PS, Malik A, Hilmi I, Qua CS, Wong CH, Goh KL. Clinical impact and risk factors for percutaneous gastrostomy wound infections due to resistant organisms. Int J Infect Dis. 2008;12:149-50.

15. Mangram AJ, Horan TC, Pearson HL. Guideline for prevention of surgical site infection. Inf Control Hosp Epidemiol. 1999;20:247-78.

16. Rao GG, Osman M, Johnson L, Ramsey D, Jones S, Fidler H. Prevention of percutaneous endoscopic gastrostomy site infection caused by methicillin-resistant Staphylococcus aureus. J Hosp Infect. 2004;58:81-3.

17. Rodríguez Ortega P, Calañas Continente A, Molina Puertas MJ, Gutiérrez Alcántara C, Benito López P, Lavado Hernández R. Gastrostomia endoscópica percutânea: 7 años de experiencia en nutrición enteral a largo prazo. Seguimiento clínico. Nutr Hosp. 2011;26:399-401.

18. Sharma VK, Howden CW. Meta-analysis of randomised, controlled trials of antibiotic prophylaxis before percutaneous endoscopic gastrostomy. Am J Gastroenterol. 2000;95:3133-6.

19. Siegel JD, Rhinehart E, Jackson M, Chiarelo L; the Healthcare Infection Control Practice Advisory Committee. Management of multidrug-resistant organisms in healthcare settings, 2006. Atlanta, GA: Centre for Diseases Control and Prevention (CDC); 2006 [Internet]. Available from: htpp://www.cdc.gov/hicpac/pdf/MDRO/ MDROGuideline2006.pdf

20. Thomas S, Cantrill S, Waghorn DJ, McIntyre A. The role of screening and antibiotic prophylaxis in the prevention of percutaneous gastrostomy site infection caused by methicillin-resistant Staphylococcus aureus. Aliment Pharmacol Ther. 2007;25:593-7.

21. Zopf Y, Konturek P, Nuernberger A, Maiss J, Zenk J, Iro H, Hahn EG, Schwab D. Local infection after placement of percutaneous endoscopic gastrostomy tubes: a prospective study evaluating risk factors. Can J Gastroenterol. 2008;22:987-91.

Received 5/6/2012. Accepted 22/8/2012 